\title{
"YONDER LIES YOUR HINTERLAND": RHODES, BAKER AND THE TWISTED STRANDS OF THE SOUTH AFRICAN ARCHITECTURAL TRADITION
}

\author{
J M Claassen (Stellenbosch University)
}

\begin{abstract}
This article considers the various strands that make up the classical architectural tradition in South Africa. In the last quarter of the nineteenth century and the beginning of the twentieth, under British rule the tradition of the Palladian style for civic buildings and of Graeco-Roman building styles for institutions of higher learning reflected the imperial ideals of South Africa's political overlords. This was the tradition in which Sir Herbert Baker had been trained and which he encountered when he reached South Africa late in the nineteenth century. South African architecture would have been less rich without the strong influence of Cecil John Rhodes' admiration for indigenous Cape Dutch architecture on Baker's architectural taste. This architecture was strongly rooted in another aspect of the classical tradition. During Dutch economic and imperial rule, the northern European style of classicistic or baroque gabling on perpendicular buildings had at the Cape been translated into the gables of sprawling low buildings. Illustrations show earlier examples of classical styles at the Cape, including examples of the second classical strain (via Holland and Germany) in South African architecture, so much admired by Rhodes. The article continues with an examination of some of Baker's best known buildings that show a blending of these two strands. It ends with some thoughts on the durability of the Classical tradition and neo-classical vestiges in post-colonial (and postapartheid) South Africa.
\end{abstract}

In our many neo-classical buildings we South Africans are constantly reminded of various strands of an architectural tradition that reached us from Greece and Rome via both London and Amsterdam. Both strands need brief exploration. The blending of these two strands by Sir Herbert Baker in the architecture inspired and mostly commissioned by Cecil John Rhodes is the topic of this article.

Politics, commerce and architecture are inevitably connected, as a brief view of South Africa's earlier history will amply show. The south-western part of South Africa was first extensively colonised by the Dutch East India Company after its earlier circumnavigation by Portuguese explorers. The motive was the establishment of a supply-post for trading vessels on their arduous way to the East. The Cape of Good Hope came under British rule in 1795, largely to serve as an outpost against potential French aggression after the French Revolution. It was soon after briefly retaken by the Dutch, who did not so easily want to lose hegemony over a valuable source of fresh supplies. The Cape and its immediately abutting interior were finally taken over again by the British in 1805, more probably now in response to the real threat posed by Napoleon's navy. Imperial tastes and classicist styles were soon reflected in the architecture of the Cape, in particular in larger buildings like churches or theatres. 
The first theatre at the Cape (Fig. 1) was designed to resemble the outlines of a Greek temple, but with buttresses, not columns. It was inaugurated in Cape Town in 1802, during the brief interim of Dutch rule, but, judging from its size, it would have been planned and the foundations laid during the first British occupation that ended in 1800. It was later turned into a church for ex-slaves and its vaguely "Greek-temple" look was altered by adding a Gothic façade. Echoes of this style are to be found in various religious buildings, such as the suitably stern "Doric" St. Andrew's Presbyterian Church in Cape Town (1828), and even some mosques.

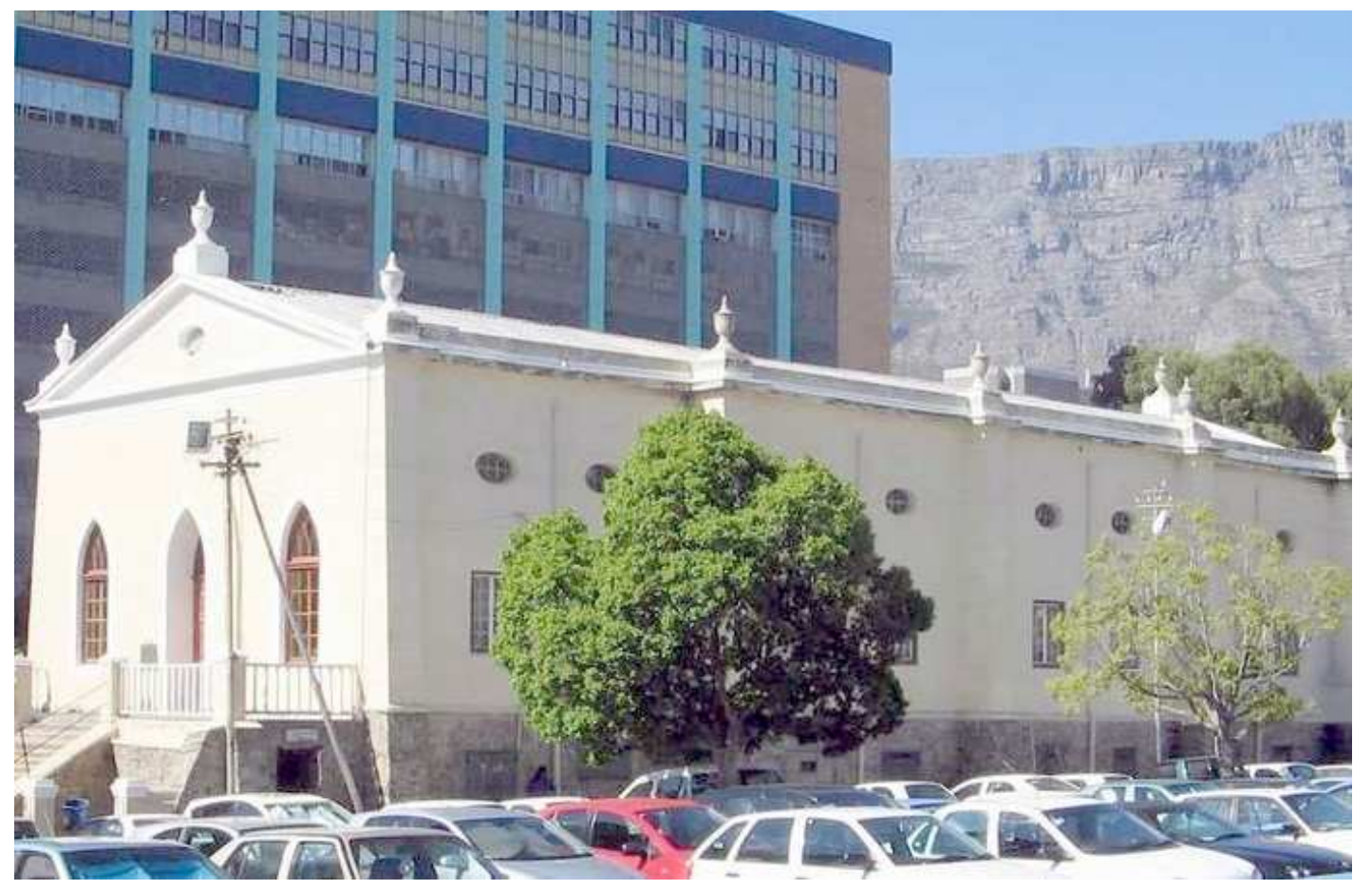

Fig. 1: St Stephen's Church, Riebeeck Square, Cape Town, 1802.

Thomas Metcalf in a monograph on British imperial architecture in India (1989: passim) avers that the British through the course of the nineteenth century became increasingly aware of the fact that they were the political rulers of an empire. In protecting established British trade interests the British government was perhaps more purposeful than were the Romans much earlier, who, it has been said, found themselves possessors of an empire, "gained in a fit of absent-mindedness".

Outright political rule by Britain may be dated to the era after the suppression of the Indian revolt of 1857. The British Raj was made manifest by the declaration in 1876 of Queen Victoria as "Empress of India". The classical tradition was seen to link it to its "Roman imperial roots".

Considering both the relationship of Cecil John Rhodes, formerly Prime Minister of the Cape Colony and finally imperialist par excellence, with the architect Sir Herbert Baker and the relationship between Baker's monumental buildings in 
Pretoria and New Delhi, Metcalf earlier wrote in an article in History Today (1986:12):

Above all, it would seem, the British sought, by connecting their monuments to the ideals and empires of a cherished classical antiquity, to enhance the moral worth - in their own eyes — of their political handiwork.

Metcalf was exploring Baker's view of the role that architecture should play in the service of empire in relation to Baker's work at New Delhi. He rightly traced influences on Baker back to South Africa and to Rhodes.

Under his patron's influence, who first encouraged him to acknowledge the charm and "classical" lines also of Cape Dutch architecture, Herbert Baker at the Cape melded two traditions, Cape Dutch and neo-classical, in various remarkable buildings. ${ }^{1}$ Both at the Cape and later in India he worked largely within the classical tradition. However, like those imperial architects that sought to encourage some form of acknowledgement also of local craftsmen and the retention of an indigenous heritage, he sought to meld aspects of the indigenous that he found in both South Africa and India into hybridised monumental buildings. By this means the might of the British Raj as natural heir to the Roman Empire would be emphasised, even though local traditions were apparently being accommodated. This attitude was rejected by many of his colleagues, for whom only unalloyed classicism was acceptable to celebrate the imperial might of Britain. $^{2}$

Within nineteenth-century Britain there was also an alternative architectural fashion. Apparently in reaction to the popular neo-classicist trend, some architects were also influenced by a desire to return to their "British" architectural roots, which for some lay wholly within the Gothic tradition. These men were influenced by John Ruskin, also famous for his inaugural lecture at Oxford that served to imbue many young Englishmen with the ideal of spreading abroad their "Englishness" for the benefit of the world. With this trend came a desire to encourage original English arts and crafts (also strongly propagated by the designer William Morris). A counter-reaction against this assumption in the various colonial administrations, so Metcalf, led to the even more active encouragement in various British colonies of the classical tradition, particularly as embodied in the neo-classicist "Palladian" style, reminiscent of Renaissance Italy's take on Rome, that was pioneered in England by Christopher Wren and Inigo Jones.

The tension between these two approaches informed much of imperial architecture. In South Africa civic buildings frequently followed the Palladian pattern.

1 The background to use of these diverse styles at the Cape is briefly sketched by Johnson 1987:1-15, 84-5.

2 In South Africa, Baker co-opted the defeated Boer generals Smuts and Botha as advisors in his greatest enterprise, whereas in India, so Metcalf, the architecture of New Delhi was apparently simply imposed, top-down, by the British powers, with no local input. 
Cape Town's City Hall (Fig. 2) dates from 1905. Its near-contemporary, the Durban Town Hall, was based on the design of the Belfast Town Hall. Both are ornate, Baroque-style buildings, built of dressed stone. In the case of the Cape Town City Hall, the rich, warm golden-brown stone was imported from the south of England.

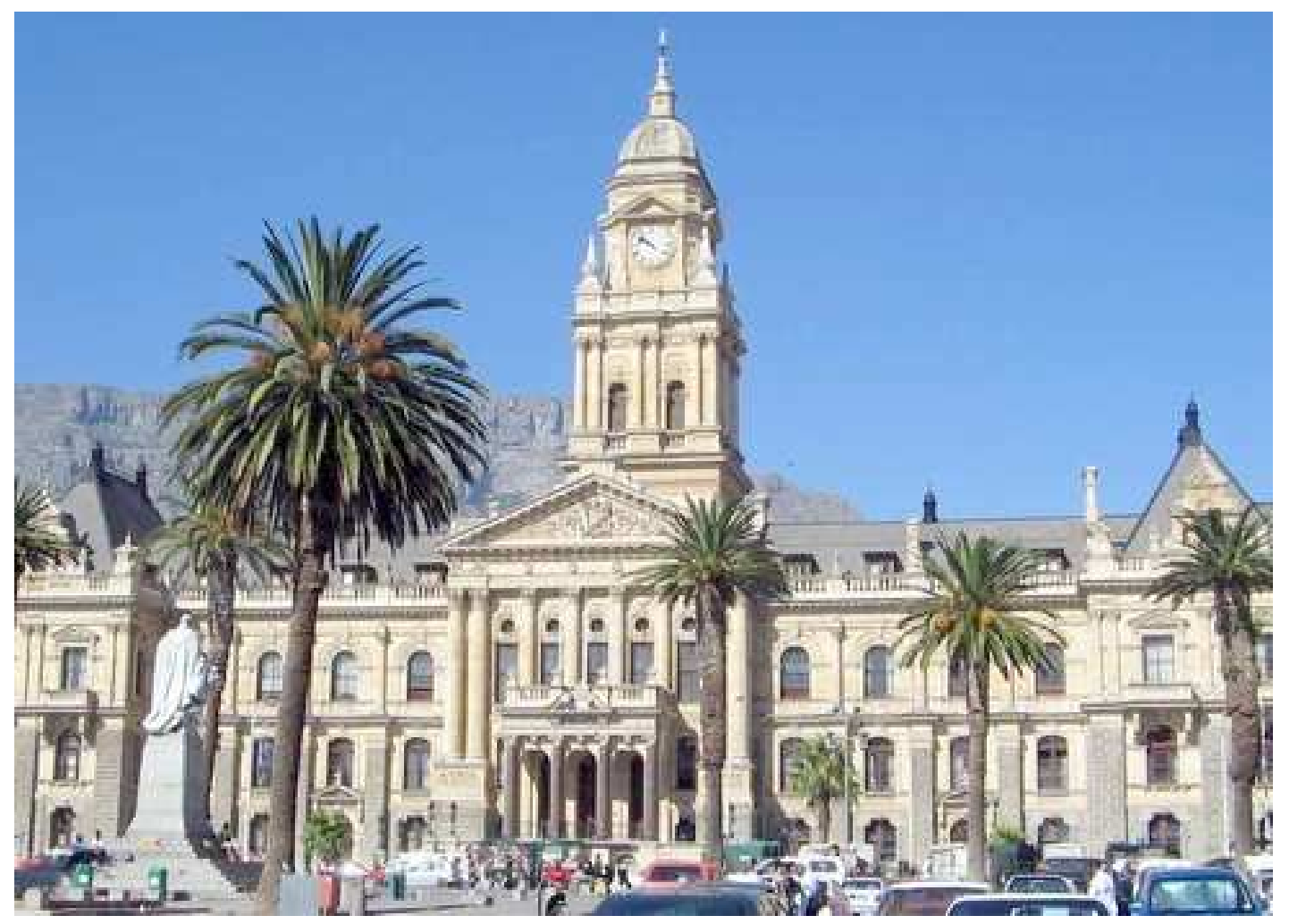

Fig. 2: Cape Town City Hall, 1905.

The classical tradition also reigned supreme in the groves and heights of colonial academe, as may be seen at Stellenbosch. The tradition of Graeco-Roman building as being the only fitting housing for institutions of higher learning influenced the choice of style for the architecture of the older buildings of Stellenbosch University, founded in the mid-nineteenth century as the Stellenbosch College, later becoming "Victoria College", that reflected the imperial ideals of its political overlords. By the late eighteen-hundreds it was seen as imperative that the nascent university be housed in Classical style. Hence "Victoria College" developed a neo-classicist architecture. Its ornate, whitewashed "Old Main Building" (Fig. 3) was designed in the early 1880 s by a German architect, Carl Otto Hager, and completed in 1886 . 
That Hager would naturally resort to a Baroque Romanesque style was not axiomatic as he was by then famous for his neo-Gothic church architecture, and he never again ventured into Romanesque. ${ }^{3}$ Other University buildings followed later, that still paid lip service, with varying degrees of success, to the Classical tradition.

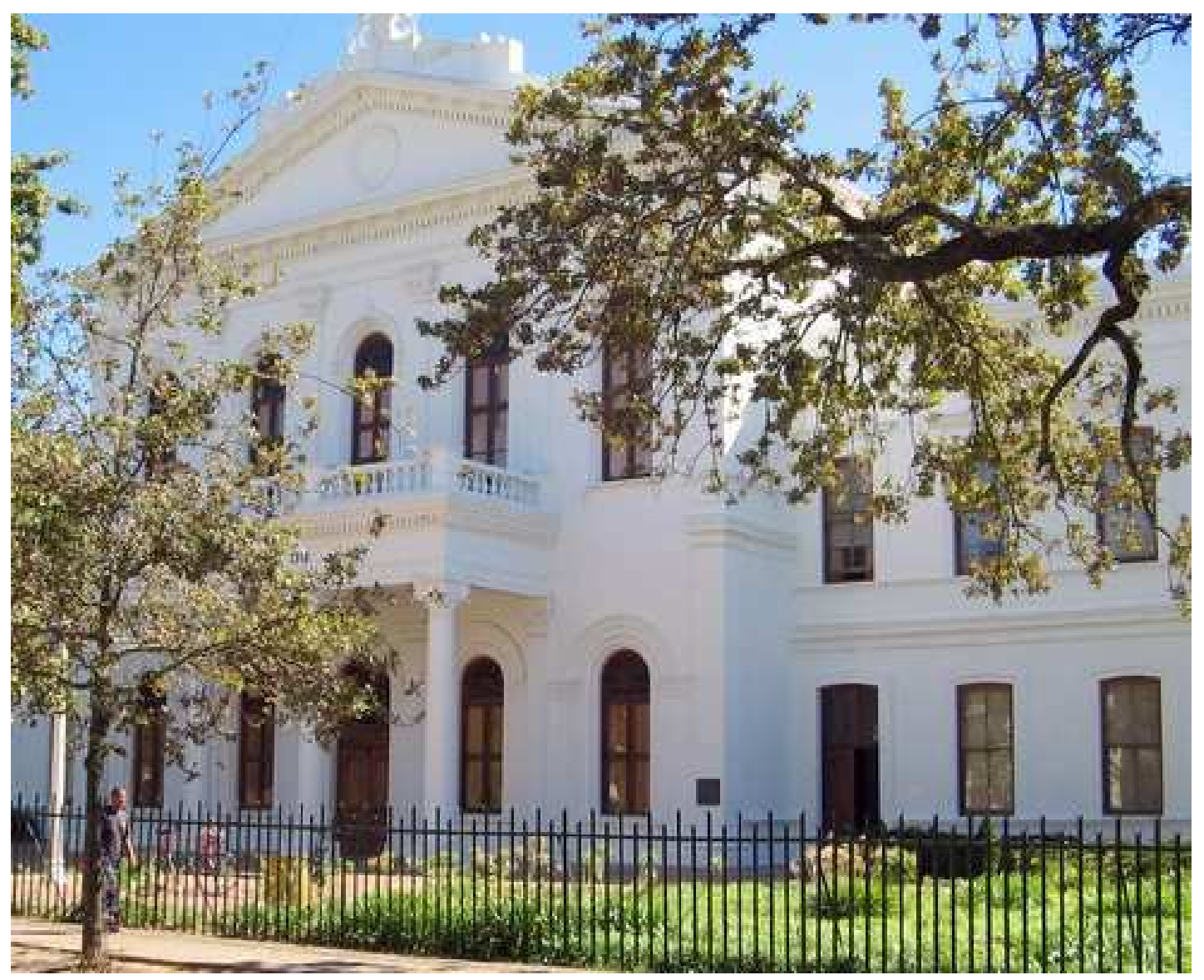

Fig. 3: Old Main Building, Stellenbosch University, 1886.

It was left to an architectural genius like Sir Herbert Baker to effect a compromise between two such apparently contradictory architectural trends. We have noted above the strong influence that Rhodes' appreciation of the local had on Baker. Let us first, then, consider Baker's mentor.

Two pictures of the man were current in my youth: In the quasi-British atmosphere of my English-medium elementary school in Cape Town (in the fifties of the last century), the myth was propagated of Cecil John Rhodes (Fig. 4) ${ }^{4}$ as a great and patriotic hero, who, so the legend went, on his deathbed complained "So much to do, so little done".

\footnotetext{
3 Sources for this building are Fensham 1986 and Hofmeyr 1993.

4 This statue stands in the Company Gardens in Cape Town.
} 
On occasion the hero pointed northward, to the African interior, exclaiming "Yonder lies your hinterland!" — actually, "Your hinterland is there!" 5

At my Afrikaans-medium high school, a different image emerged, of Rhodes as an imperialist lackey who did his best to bring South Africa under the oppressive heel of Britain. The truth probably lies somewhere between these extremes - or rather, in the centre of a triangle, for the black historians of the new South Africa may paint a different picture again of the man who cynically usurped vast tracts of the African hinterland and did much to strengthen racist rule in southern Africa. ${ }^{6}$

In the early nineteen hundreds many biographies of Rhodes were written; mostly by other upholders of the traditions of the British Raj, one even with the pseudonym "Imperialist". Their tendency is predictably Jingoist. The prize must go to the architect whom Rhodes so frequently employed and so profoundly influenced: Herbert Baker (1934) writes of the great man in breathless, hero-worshipping awe. ${ }^{8}$ The main virtue of Baker's book is the light it sheds on the architecture and art inspired and most often financed by Rhodes.

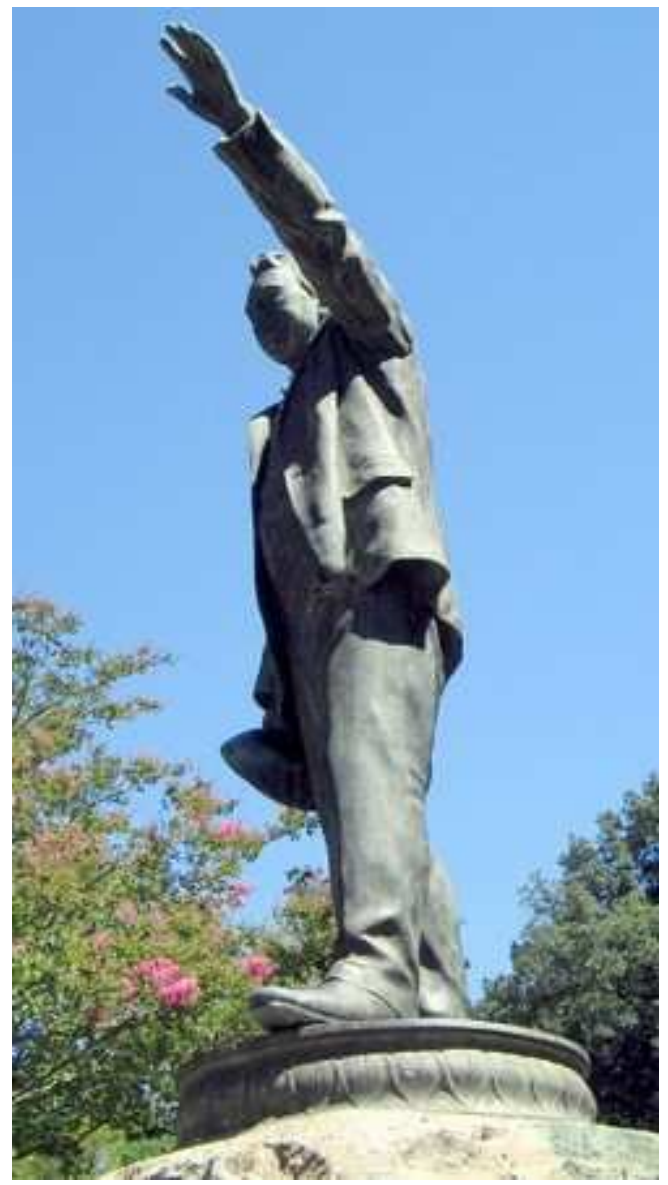

Fig. 4: Statue of Rhodes pointing to the North, Company Gardens, Cape Town.

5 The latter wording occurs on the base of the Company Gardens statue (Fig. 4). I have been unable to ascertain the origin of the more romantic wording, which I have incorporated into the title of this article. It simply formed part of the romantic Rhodes-myth that I was fed as a young child. Maylam 2005, discussing "the cult of Rhodes", does not refer to the alternative version.

6 It is difficult today to write of Rhodes sine ira et studio. In our postcolonial era the ideals of empire and much of what Rhodes stood for is increasingly questioned, if not derided. Rhodes himself is still an enigma, despite the twenty-six biographies featured in Maylam's 2005 bibliography. Maylam 2005:6 designates him as "at best a benevolent paternalist, at worst a crude white supremacist". However, analysis of Rhodes' character is not the aim of this article.

7 See the bibliography below. As all give largely the same details, with slight differences in emphasis, sources for what may be accepted as common knowledge will not be individually acknowledged hereafter. For a recent update on publications relating to Rhodes, see Maylam's 2005 bibliography.

8 A salutary antidote to these is the translation (2003) from the Russian of a scholarly but readable Communist-era overview (1984) of Cecil Rhodes and his time by Apollon Davidson. Both its mildly anti-British and critical, anti-capitalist approaches accord with the sentiments of the majority of modern South Africans. 
Various statues of Rhodes scattered throughout Cape Town represent the man and his ideals in diverse ways, from G F Watts' idealised "Spirit of Energy" at the foot of the monument designed by Baker (to which we'll return) to Henry Pogrum's representation of Rhodes' hankering for "his North" in the Company Gardens (Fig. 4). ${ }^{9}$ This bronze figure, with raised left hand, is perhaps the most "imperial" of the Cape statues of Rhodes. Its stance is strongly reminiscent of the so-called "Prima Porta" statue of the Emperor Augustus in Rome, although its realism contrasts with the Roman statue, as well as with the nearby calmly regal statue of Queen Victoria, executed in white marble, in front of the Houses of Parliament. ${ }^{10}$ The inscription on the base of the Rhodes statue ("Your hinterland is there") explains the reason for the outstretched hand, which, incidentally, now reaches out toward the successful urban renewal project and upmarket inner city living for the affluent (entitled "MandelaRhodes Place") two blocks away. However, the gesture, although made with the subject's left hand, is an open-handed Roman-style "greeting", rather than any emphatic "pointing to the North". Another statue, of a seated Rhodes, placed at the foot of the Upper Campus of the University of Cape Town ${ }^{11}$ offered a recent easy target for student pranksters. The hero, here portrayed in something of the same pose as Rodin's "Thinker", was kitted out with a gaudy cloak and a "vuvuzela", the ubiquitous rowdy plastic bugle that is joyfully blown by spectators at South African sports events. None of these statues, except, perhaps, the last, would, mutatis mutandis, have been out of place in imperial Rome.

Cecil John Rhodes became Premier of the Cape in 1890 after having amassed a fortune in the diamond fields of Kimberley. At about this time, gold was discovered on the Johannesburg Reef and the interior of South Africa became valuable to British commerce. Rhodes and his friend Leander Starr Jameson sought also to exert their influence there, ostensibly to protect the many British diggers who did not enjoy the franchise within Kruger's Boer Republic of Transvaal, within which the goldfields lay. To skip over all the nuanced history that lies in between, suffice it to say that, after the British victory over the Boers of the Transvaal and Free State in 1903, the South African interior also came under British rule. However, in 1910 independence was gained with the declaration of a Union of the Cape and Natal Colonies with the two formerly autonomous "Boer republics". ${ }^{12}$

The importance of Rhodes in forming the imperialist vision of his architect cannot be overstressed. His various biographers quote Rhodes as saying that "through art Pericles taught the lazy Athenians to believe in Empire", but there were apparently nuances to his own ideas about art in the service of empire. Rhodes' political views were not as simply British Jingoist as they are often portrayed. His last will and testament spells out in detail practical arrangements for the establishment of the

$9 \quad$ See Maylam 2005:120.

10 Unlike the stylised "imperial" dress given the Roman emperor, Rhodes' clothing looks distinctly "baggy" and clearly represents his usual manner of dressing. The gesture also seems vaguely to emulate that of the equestrian statue of Marcus Aurelius on Michelangelo's piazza on the Capitoline. However, both Classical statues have their right hands raised.

11 Marian Walgate 1934. See Maylam 2005: 57, 121.

12 In 1961 Dr. Verwoerd took South Africa out of the British Commonwealth, but after 1994 South Africa returned to the fold. 
system of scholarships that bear his name. It was annotated and published shortly after Rhodes' death by Stead (1902), who gave a detailed explication of Rhodes' ideas, first adumbrated in 1877, when he was only twenty-four, soon after Queen Victoria became "Empress of all India".

Rhodes never outgrew his youthful fantasies. They may briefly be summarised as follows:

It behoves the "English race" as the "pinnacle of Creation", to unite in a worldwide federation in order wisely to rule the "darker races" of Africa and Asia under precepts similar to those of the Constitution of the United States of America, but with local Home Rule. Whether under an American president or British king is immaterial. In order to bring such a federation about, a sort of secular "Church" of like-minded young men should be created and, like the Jesuit Order in ecclesiastical affairs, it was to influence secular affairs worldwide. ${ }^{13}$

This was the reasoning behind Rhodes' institution of the scholarships that over the years brought hundreds of bright young men (and, more recently, women) from the colonies and from the United States (a few even from Germany) to Britain for further education. ${ }^{14}$ They were meant to return at the end of their studies to foster Rhodes' ideals in high places in commerce and government.

Rhodes' imperialism was hence a cultural imperialism of 'Englishness', not mere power - the British version of the Herrnvolk-fantasy, in the spirit of John Ruskin's inaugural lecture at Oxford. ${ }^{15}$ Rhodes saw the acquisition of money as a means to that end. Even his incursion into Bechuanaland, now Botswana, and the settlement of colonists in what became Rhodesia, now Zimbabwe, were meant to feed his dream of "painting the whole world pink" (the colour used for British imperial possessions on older political maps of the world). Even America had to be brought back into a common English fold. ${ }^{16}$

At first Rhodes strongly repudiated the "imperial factor" and at the Cape tried to effect a compromise between English and Dutch, or rather, Afrikaans, interests, but after the disastrous incursion into the Transvaal under Jameson in 1895, the Afrikaners in their turn repudiated him. Rhodes perforce had to fall back onto the imperialists for support in his grandiose ideas of a federation of Southern Africa, which would include the vast Hinterland up to the borders of Kenia, and would support railway and telegraph expansion from the Cape to Cairo. His "Cape to

13 My own précis of the editorial notes and Rhodes' own wordy preamble to his last will and testament, as edited by Stead 1902.

14 Maylam 2005:12, 30, 60-77 implies that supreme egoism and a quest for immortality lay behind Rhodes' more magnificent educational and architectural projects. Such scholarships were originally mooted by Atsley Cooper in 1891, the idea fitting so well with Rhodes' idea of a "secular church" that Rhodes adopted it (id. 77).

15 First mooted by Charles Dilke in 1869, Marlowe 1972:7-8.

16 Rhodes' ideas changed over time, probably to the relief of his executors, who did not after all have to carry out Rhodes' initial impossible injunction to annex the USA. 
Cairo" ${ }^{17} \operatorname{logo}$ is a model of boyish amateurism, with a symbolic farrago of images. A stylised crescent moon and pyramidal "Mountains of the Moon"18 surmount a stylised "source of the Nile". These are enclosed within a schematic representation of the Southern Cross, flanked by two depictions of Rhodes' own favourite stone images of birds from Greater Zimbabwe (Baker 1934: cover and title page). ${ }^{19}$

The culture Rhodes acknowledged was the culture of a young Englishman of his day, an Oxford graduate with knowledge of the Classics. Gibbon was his guiding light. In spite of his arduous accumulation over a period of eight years (between stints of mining and commercial enterprise) of the requisite number of terms in residence at Oxford to achieve a BA, lack of truly scholarly skill in Latin and Greek (plus sufficient wealth) led him to commission new typed and bound translations of all Gibbons' sources (even those already available in English). This enterprise ended abruptly at $£ 8000$, when Rhodes apparently decided that he now had enough culture to hand. Rhodes is said by Baker to have resembled the Roman emperor Titus in features (Baker 1934:133) and saw himself as a new Hadrian, expander of empire. The Hadrianesque baths that Baker was commissioned to design as a monument to the siege of hot and dry Kimberley were, however, never built. Baker ascribes this to Rhodes' failing health (id. 51). He scarcely outlived the war.

Rhodes' acknowledgement of the need for Home Rule in minor matters within the colonies, as concomitant to his greater ideal of a larger English hegemony (much like the Roman imperial custom), made Rhodes enthusiastic also for the preservation of Cape Dutch architecture and the extension of its style, interwoven with the classicistic "Palladian" style of Jones and Wren, which we have seen was already established in South Africa in various forms. Herbert Baker was consequently encouraged to create an eclectic mix of "indigenous" (i.e. Dutch, not black African) and classical styles at the Cape, in the face of the prevalent Victorian mania for wrought-iron work and neo-Gothic structures (cf. Greig 1970:29, 41, 265-8). Rhodes' secretary Pickstone was commissioned to buy up farms with Cape Dutch gabled houses on them. Baker was entrusted with reconstructing these, which gave ample scope for the employment of vernacular crafts (Johnson 1987:84-7).

The Cape Dutch architecture that so impressed both Rhodes and Baker also had its roots in both northern and southern Europe and also influenced the adoption of classical models in South African architecture. Its antecedents may be briefly described. During Dutch economic and imperial rule at the Cape either classicistic or baroque gables like those common on three- or more storied

17 Merrington 2001:330 discusses the popularity of alliterative slogan, suggesting (quoting Stead) that this very alliteration was what drew Rhodes to the concept. It was first mooted by Lord Gifford, Maylam 2005:146.

18 According to Merrington 2001:329-37 such emphasis on "Egyptianising" derived partly from Sir Henry Morton Stanley's designation of the mountains as "an Egyptian pyramid" and partly from the neo-Hegelian concept of Africa with "no history" except for the "Semitic" civilization of Egypt, the whole deeply suffused with Masonic symbolism.

19 The logo was designed by Baker, whose penchant for heraldic design was also employed to design heraldic shields for various Indian provinces, see Metcalf 1980:12. The soapstone birds in Shona culture were considered to be mediators between the dead and the living, so Maylam 2005:157, but whether Rhodes was aware of this, is uncertain. 
perpendicular buildings in the Netherlands, parts of Germany and Denmark ${ }^{20}$ were translated into the equally classicistic or baroque gables on low, single-storied buildings (Fig. 5).

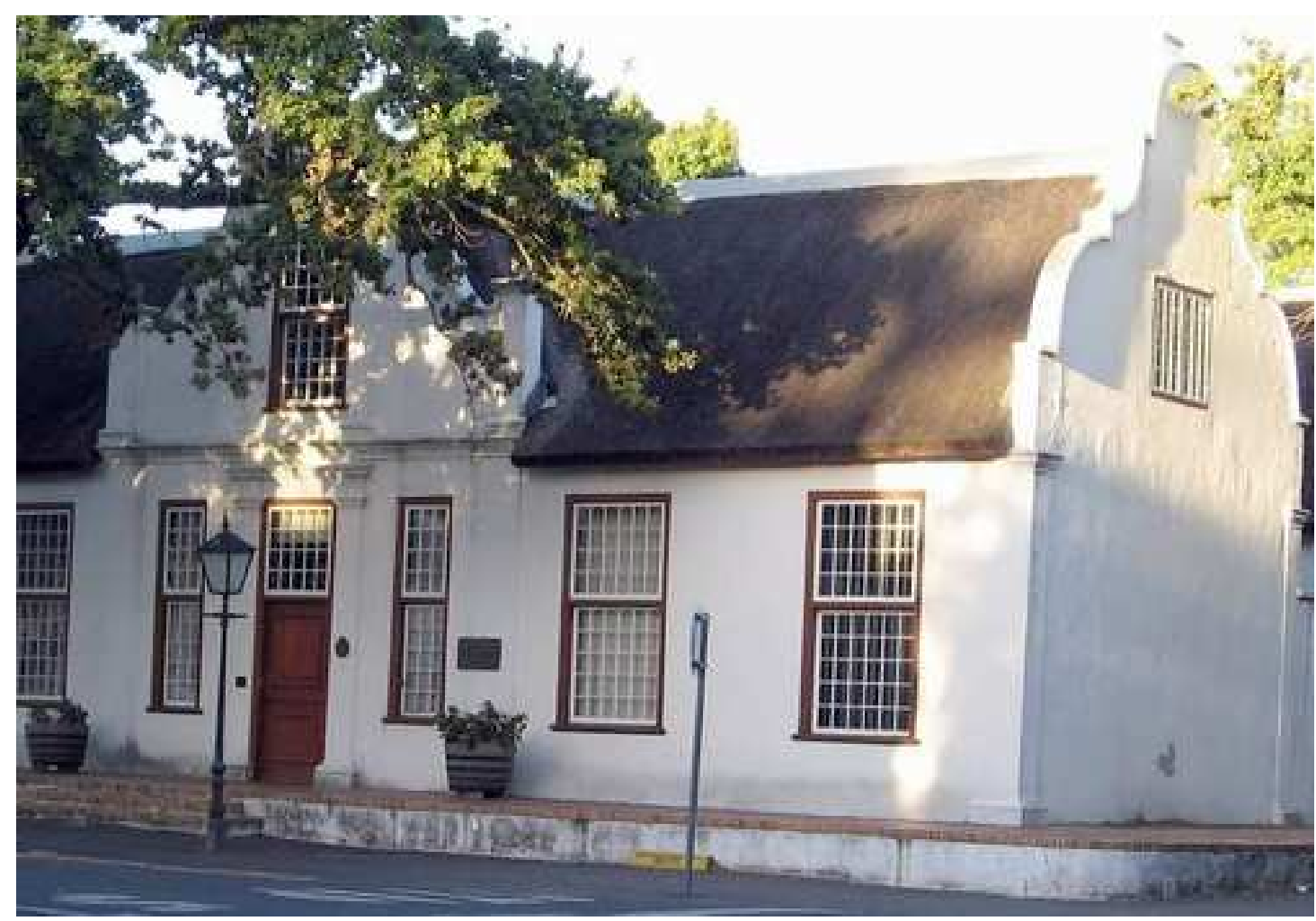

Fig. 5: "Utopia" (offices of the Dutch Reformed Church), Drostdy Street, Stellenbosch, an H-shaped house with baroque gables.

Availability of land was no problem under the wide African skies, hence these buildings sprawled over a wide footprint. Cape Dutch architecture was further constrained by the availability of materials. U- or $\mathrm{H}$-shaped floor layouts were necessitated by the height (or lack of height) of trees available for rafters, which placed constraints on the potential width of buildings. Whitewash for annual application over clay plastering of walls of unbaked clay bricks was readily available. Wooden doors, window frames and the ubiquitous half-shutters were often painted dark green to preserve them from the burning summer sun. Use of unbaked bricks dictated the extreme thickness of walls, ensuring that houses were cool. The most readily available roof covering was thatch (Fig. 6).

Many simple farm houses were extremely primitive, especially in the early years, but affluent wine farmers in the Western Cape, whose families had by then resided in the same area for more than a century, during the late eighteenth and early nineteenth centuries built austere, but elegant mansions with many Classical features, using not only locally-available materials, but importing teak and beautiful fired clay

20

Johnson 1987:84 
floor tiles from the east. This was the gabled style much admired by Rhodes that he asked his architect (who had sketched similar gables on visits to Holland and Belgium) to replicate.

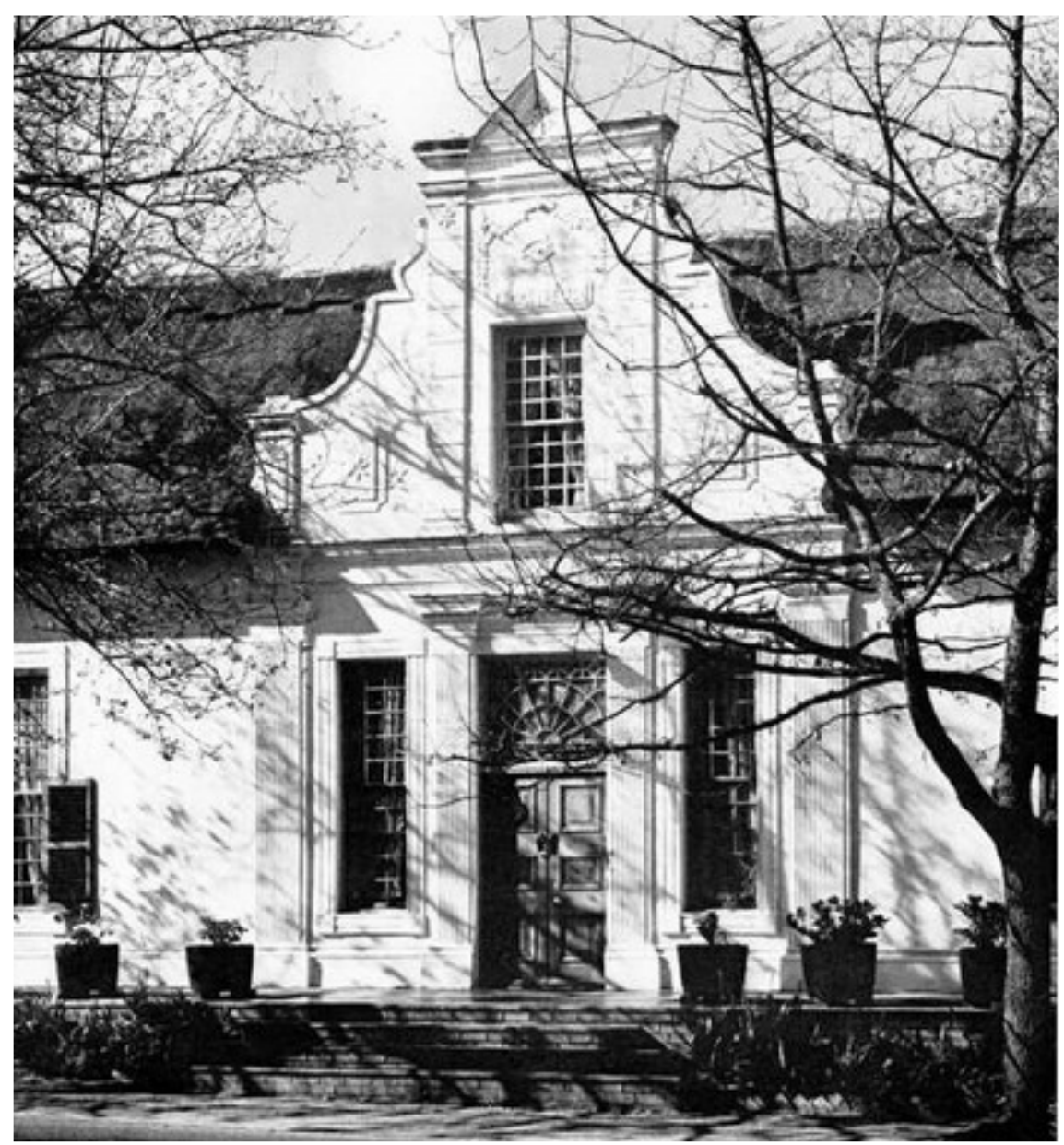

Fig. 6: "La Gratitude", Stellenbosch, with its thatched roof, pedimental gable and Classical pilasters. Source, Mertens 1971.

Baker's first great masterpiece at the Cape was the restoration (twice, for it burned down shortly after its completion in 1896) of "Groote Schuur" ("great barn", Fig. 7), ${ }^{21}$ which Rhodes later bequeathed to the Cape Colony as a fitting home for its Premier, It is now one of the official Presidential residences, but is also treated as a museum. Groote Schuur is not authentically "Cape Dutch" in all its details, some parts of its amalgam sitting rather uncomfortably together. It has a classical colonnade, a tiled roof, not thatch, and its twisted chimneys seem out of character. ${ }^{22}$

21 It originally was a barn built to house the East India Company's grain stores. It was renamed by President Mandela "Genadendal”, dale of Mercy, after the eighteenth century German mission station some $160 \mathrm{~km}$ from Cape Town.

22 Johnson 1987:87-8 speaks of a "strange combination of fancy and fact". He suggests that Rhodes was "genuinely deluded" to want gables on a building that would be "both Georgian and classical". Its spiral chimneys he considers to resemble the Tudor chimneys at Hampton Court. 
Yet it is more "Dutch" than "English" in execution and style (for example, it has Cape Dutch-style half shutters on its downstairs windows).

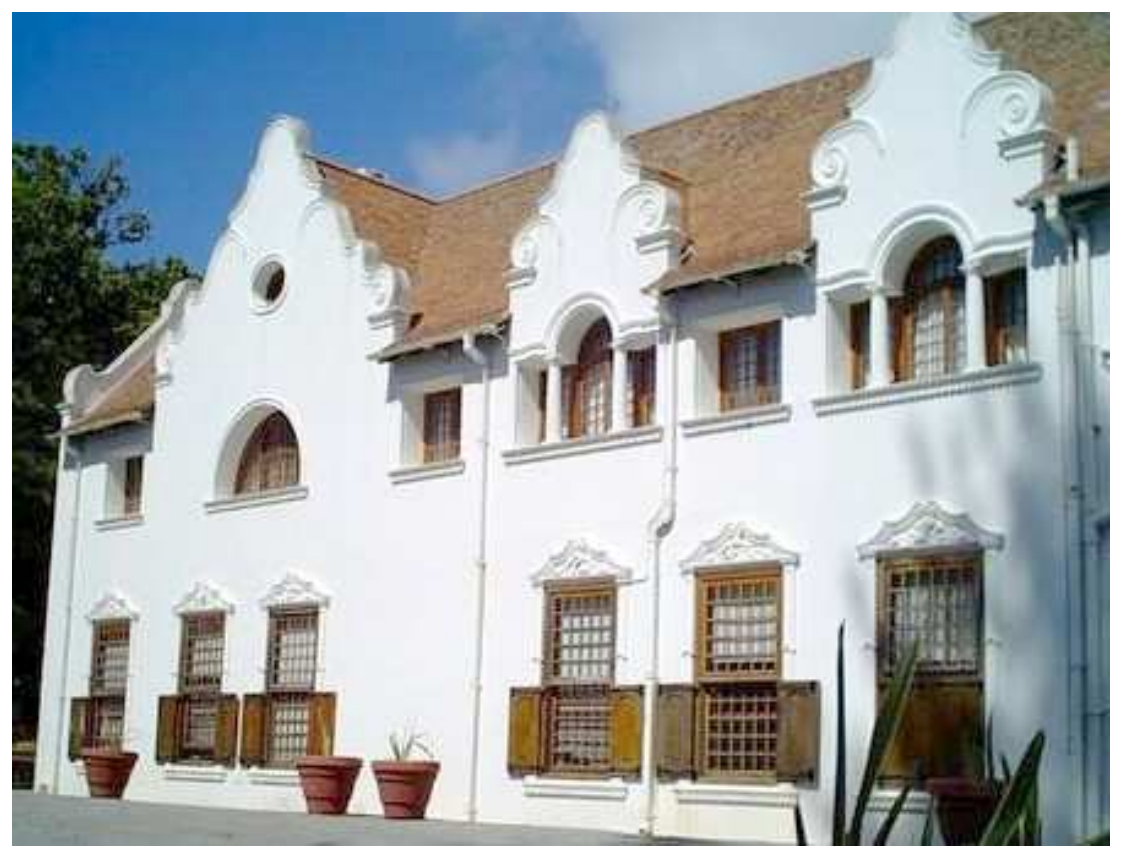

Fig. 7: Groote Schuur, $1896 .{ }^{23}$

A spirit similar to that of Morris' "Arts and Crafts" movement seemed to lie behind his encouragement of local craftsmen to forge brass or copper nails and hinges instead of using shoddy imports. Baker's own architectural training in late nineteenthcentury England and his membership there of a "Crafts Revival" discussion group would have imbued him with the same enthusiasm for the local and hand-made (cf. Greig 1970:19-20). Rhodes had Baker scour the countryside for suitable old Cape Dutch furniture for the mansion. ${ }^{24}$

After the completion of Groote Schuur Rhodes sent Baker on an extensive allexpenses-paid cultural tour of Greece and Italy, further establishing Baker's taste for both Classical Greek and Italian Renaissance (that is, "Palladian") building styles. His monument for the War dead at Kimberley is a starkly simple cenotaph in the style of a Greek tomb Baker had seen and sketched at Agrigentum (Baker 1934:53). The granite "Greek temple" (Fig. 8) on the eastern slope of Devil's Peak, abutting to, but roughly south-east of Table Mountain, was designed by Baker after Rhodes' early death at forty-nine, as monument to Rhodes and his British imperial aspirations for

\footnotetext{
23 http://www.igougo.com/journal-j17834_Cape_Town_Facing_the_Past_Historical_sights_in_ Cape_Town.html (accessed June 2009).

24 Baker's other masterpiece in Cape Town was the Anglican Cathedral of St George, which he built in the Norman style of the Aquitaine area of France, which he used to visit as a young man. The Norman style in essence also owes a debt to Rome, both in its basilica-shape and in the semi-circular arches that span its nave. Interestingly, it was erected next to and meant to replace a far more "ancient classical-style" building, shaped like a Greek temple, which I can still remember as partly in use when I was a child.
} 
Africa. Today, with ample parking and a restaurant, the monument is a favourite haunt of tourists (and muggers).

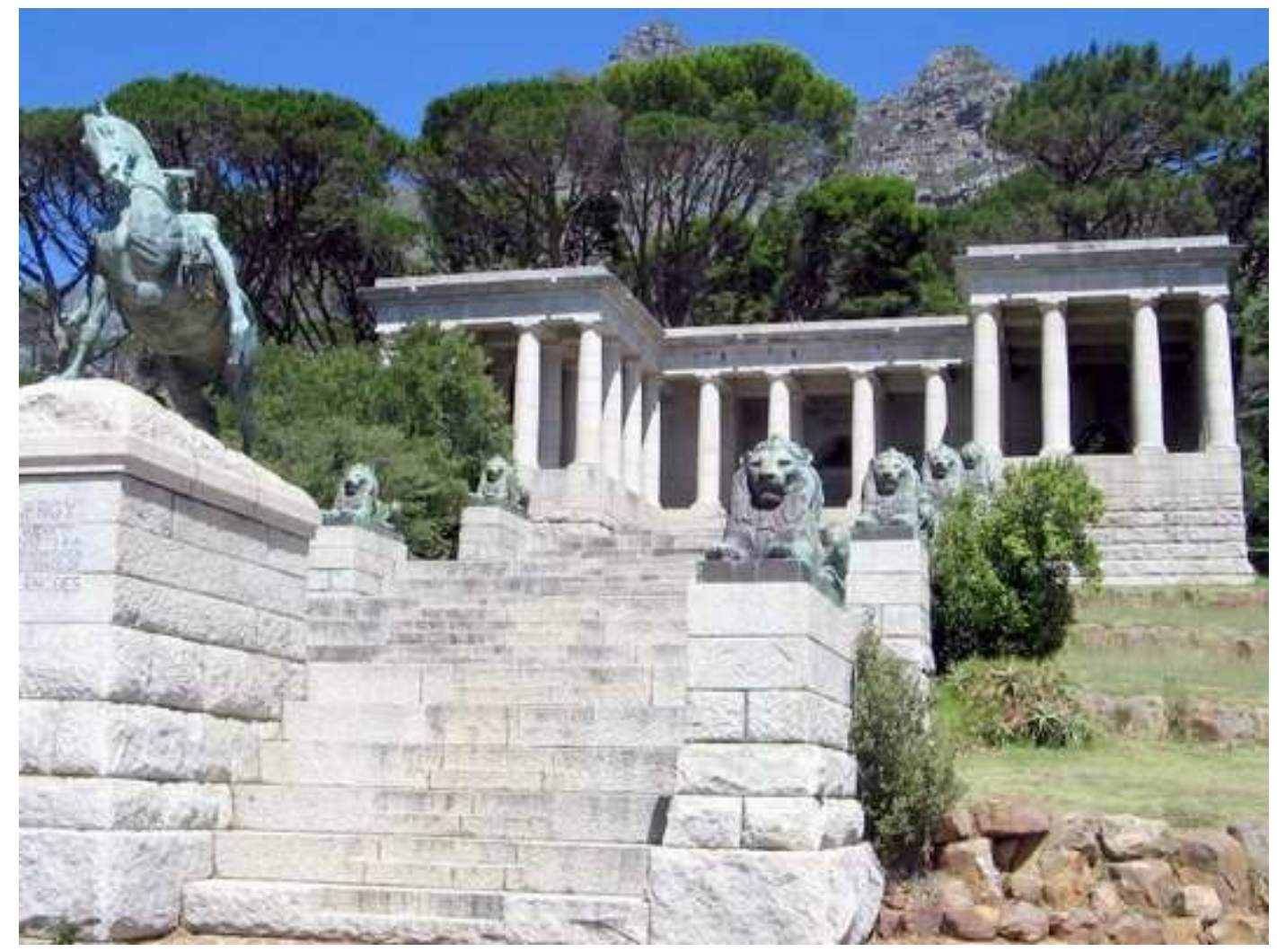

Fig. 8: Baker's monument to Rhodes, Cape Town, 1902.

The Rhodes monument was reputedly based on the famous ruins of the temple to Venus Erycina at Segesta. However, it more closely resembles the (Greek) altar of Zeus at Pergamum, or even of the (Roman) Sullan-era Fortuna Primigenia sanctuary at Praeneste (ancient Palestrina), but with truncated wings. It is essentially a winged façade, intended to look imposing from the flat plain that is Greater Cape Town. ${ }^{25}$ In form it is very similar to its near-contemporary, the neo-Classical monument to Victor Emmanuel on the Capitoline at Rome, which was built, so Edwards (2008:351) in "the international Beaux-arts style (a style already associated with the imperialist projects of other western governments)". That a monument to Rhodes would carry reminiscences of the great unifier of the Italian state may very well have suggested itself as a fitting tribute to Rhodes by his admiring architect. The Rhodes monument is, however, much narrower, ${ }^{26}$ and its sober grey granite and simpler architrave are less flamboyant than the brilliant white marble and ornamental roof of

25 Although the solid dressed granite back wall of the colonnade has several openings, there is nothing behind it, except access to the parking lot and restaurant.

26 Its central colonnade has only four columns as opposed to more than a dozen on the Roman monument. Consequently, its two wings gain prominence through contrast, whereas the wings of the Roman monument seem dwarfed by its central, slightly curved colonnade. 
the Roman edifice. This Roman monument, in its turn also reminiscent of the sanctuary of Fortuna Primigenia at Praeneste, was begun in $1885^{27}$ and its progress must still have been an object of considerable interest when Baker visited the city, while on the grand tour that was paid for by his patron. Both monuments, like the sanctuary at Praeneste, exploit the natural slope of the terrain to accommodate an impressive approach to a focal point. ${ }^{28}$

Both monuments feature an equestrian statue representing the heroic honorandus. It seems plausible that the placement of the equestrian statue of Victor

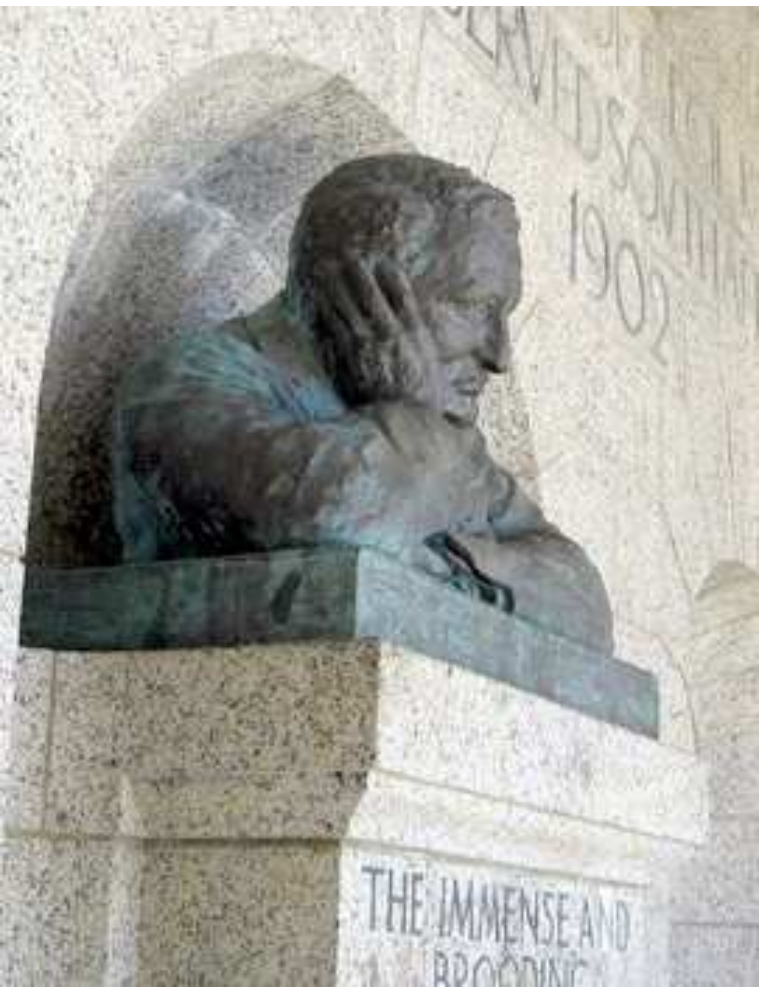

Emmanuel suggested to Baker the placement of the statuary of the Rhodes monument. The Roman king's mounted statue stands at the apex of a symmetrical series of steps leading from a first platform placed above a rather shallowly-stepped grand staircase, with further steps leading from the rear of the statue's base to a final platform. ${ }^{29}$ In Baker's masterpiece, a flight of steps, flanked by eight lions (symbolic of both imperial Britain and untamed Africa), leads up from Watts' symbolic "Physical Energy" ${ }^{30}$ to a Doric colonnade housing a colossal bronze head of Rhodes (Fig. 9) and adulatory lines by Kipling. ${ }^{31}$ Incidentally, the head faces toward the East, not northward, although its gaze is slightly averted and could be construed as vaguely "north-facing".

Fig. 9: Bust of Rhodes at his monument.

27 Edwards 2008:350-5 gives a useful overview of the political and archaeological implications of the nineteenth and early twentieth century Italians' appropriation of ancient Rome for essentially propagandistic purposes. That a monument to a modern Roman king would be placed on the ancient symbol of Republican Rome was not universally applauded.

28 See Blagg 1983:30-1 on the sanctuary as an example of "the Roman appreciation of how the natural landscape and the architect's creation might complement one another".

29 Edwards 2008:351 is worth quoting: "The heroic equestrian statue of the king echoes that of Marcus Aurelius, the centrepiece of Michelangelo's nearby Capitoline piazza”.

30 Maylam's second chapter 2005:31-62 discusses Rhodes' obsequies in 1902 (as "four funerals and a burial", p. 32) and the various monuments to Rhodes, quoting the contemporary derisive designation of the prudishly stylised nude mounted figure as "a eunuch astride a gelding".

31 "The immense and brooding spirit still / shall quicken and control. / Living he was the land and dead / his soul shall be her soul". See Maylam 2005:101 for a more positive judgment of what to me is overwrought doggerel. 
Such training rendered Baker eminently suitable as architect in 1910, long after Rhodes' death, of the Union Buildings (Fig. 10) in Pretoria for a united South Africa. The Union Buildings were, on Baker's insistence, erected on a small hill where, again like the Victor Emmanuel Monument, they are visible from miles away, rather than on the flat plain favoured by the ruling faction. In this choice, he carried the influential ex-Boer generals, Botha and Smuts, with him. Its comparative austerity and subtle Cape Dutch touches, such as half-shutters on the windows, contrast with the Palladian excesses of its exact contemporary, the Durban City Hall, which we have noted, is an almost exact replica of the Belfast City Hall in Northern Ireland, itself a "colonial" building of a kind.

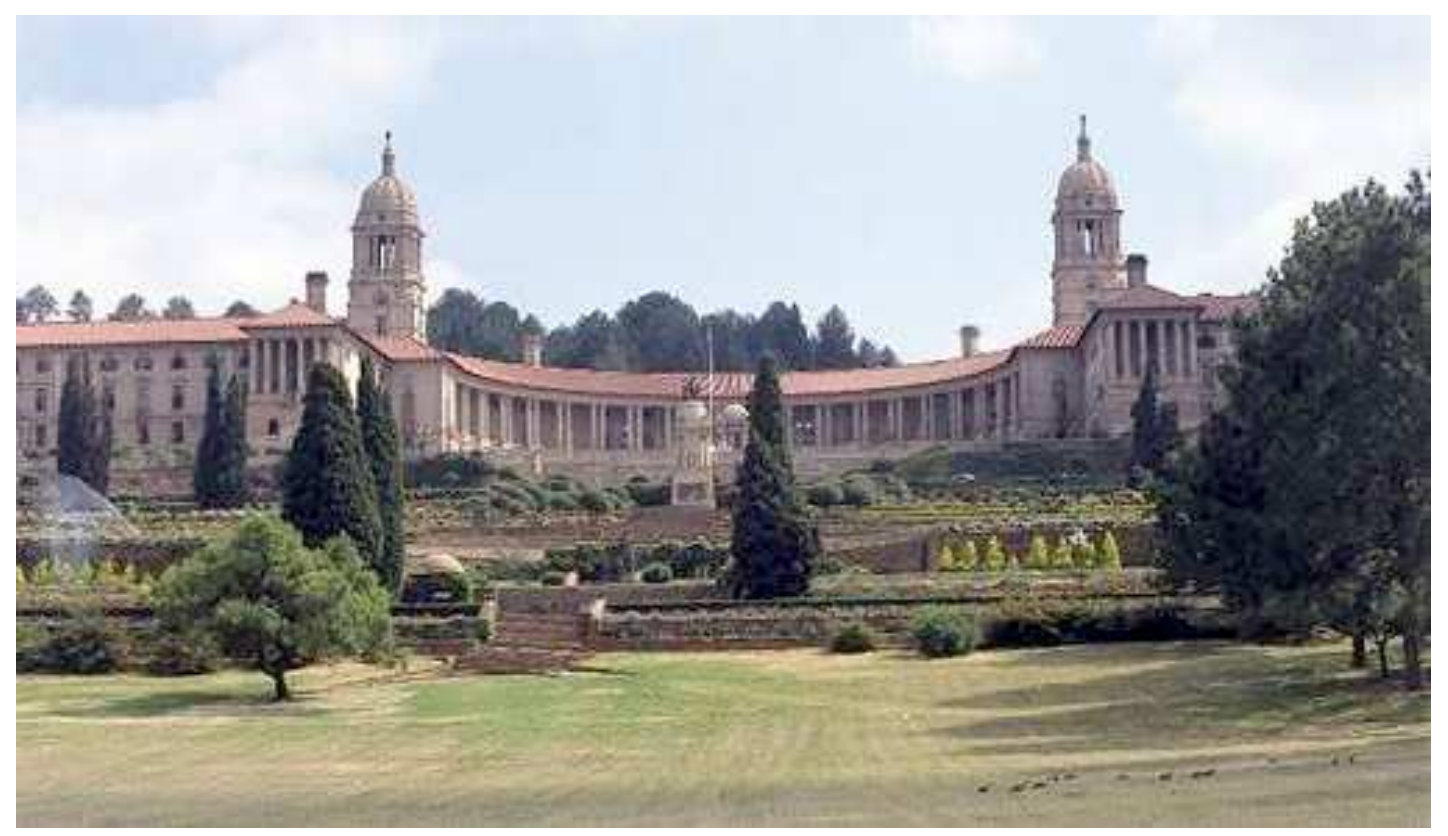

Fig. 10: The Union Buildings, Pretoria 1910. ${ }^{32}$

Whereas Baker's Rhodes Monument is reminiscent of the monument to the Italian king, but on a much smaller scale, the Union Buildings may be considered vaguely to resemble the same monument, but on a grander, one could say, colossal scale. Its monumental appearance from the flat plain below, its symmetrical, stepped approach that again exploits the natural slope of the terrain, its central exedra and colonnaded wings also clearly suggest the sanctuary of Fortuna Primigenia at Praeneste. ${ }^{33}$ Unlike both the sanctuary and the two monuments we have so far considered, here we have a complex of buildings large enough to house a whole state administration, but so laid out as to appear from a distance as a similarly winged façade. The two wings, connected by an extensive colonnaded exedra, were meant to represent the Afrikaans-

\footnotetext{
32 http://www.essential-architecture.com/.../ARCHITECT/ARCH-Baker.html. (accessed March 2008).

33 This resemblance was first pointed out to me by Professor Rolf Schneider of the Kaiser Maxmillian Institute when we both attended the recent South African Classical Association Conference at the University of Pretoria.
} 
Dutch and English parts of the white South African citizenry. Below the exedra, termed by Evans (2007:143) a "semi-circular stoa", a series of shallow stepped terraces create the effect of a Greek theatre, complete with orchestra and scaena below. $^{34}$

The Union Buildings, too, incorporate an equestrian statue in their monumental layout, but here the mounted representation of General Louis Botha (first premier of the Union) stands on the flat plain below, and does not form any sort of strong focal point as in the approaches to the monuments of Victor Emmanuel and Rhodes.

Initially Baker planned another monumental building to complete the complex, a "Temple of Peace" which, however, never came to fruition. Baker continued to live in the Pretoria area for many years, where he had earlier designed a monumental Romanesque train station for Pretoria, which, sadly, was recently burned down (but has subsequently been restored). His residential designs grace many of the more affluent older suburbs of Pretoria, but also farther afield, such as the midlands of Kwazulu-Natal. Baker influenced many of his younger contemporaries. Like Lord Milner, the civil ruler of the vanquished republics after the Anglo-Boer War, Baker also had a coterie of young men surrounding him that was termed his "kindergarten". To them he imparted his and Rhodes' ideas about melding the classical with the local. ${ }^{35}$ After Delhi he designed state buildings in other parts of the British Raj (for example, Kenia) in a similar spirit.

Such, then, was the combined legacy of Rhodes and Baker.

Let me conclude with a return to the relationship between empire and architecture. If we acknowledge economic moguls as the global imperialists of the twenty-first century, the connection between the Classical tradition and empire still holds good. Two prime examples of neo-classical architecture that serve as monuments to economic hegemony may be ascribed to the twin empires of commercial globalism and electronic communication. Near the glass-and-concrete neo-Palladian Canal Walk shopping mall with its economic apartheid of inaccessibility by any other means than private motor cars (not available to most of South Africa's teeming poor) rise the hubristic columns of a neo-Roman "temple" of massive,

34 Evans 2007:156 emphasises the phenomenon that the central city of Pretoria is, as it were, embraced by two Greek-style theatres that face one another: the slope of the hill that has the Voortrekker Monument at its apex was utilised as a Greek theatre with an orchestra and seating for twenty thousand people.

35 Another well-known South Africa architect, Gerhard Moerdijk, known for his work on the vaguely Art-Deco Voortrekker Monument of 1938, although in 1912 achieving a first place in "Classical Architecture" within the entire British Commonwealth at the London School of Architecture, chose not to join Baker's "Kindergarten" and eventually was known rather for his work in Byzantine style (Vermeulen 1999:35-49). However, Evans 2007 makes a strong case for Moerdijk's Classical training as underpinning much of his approach to this monument, especially as regarding its interior. Incidentally, the Voortrekker Monument is $1600 \mathrm{~m}^{2}$ (or 40 metres squared) in extent, and not $40 \mathrm{~m}^{2}$ (or 40 square metres), as Evans has it (p.145). 
Baalbekkian proportions, (Fig. 11) suitably devoted to a latter-day Mercury, the great god of telecommunication. ${ }^{36}$

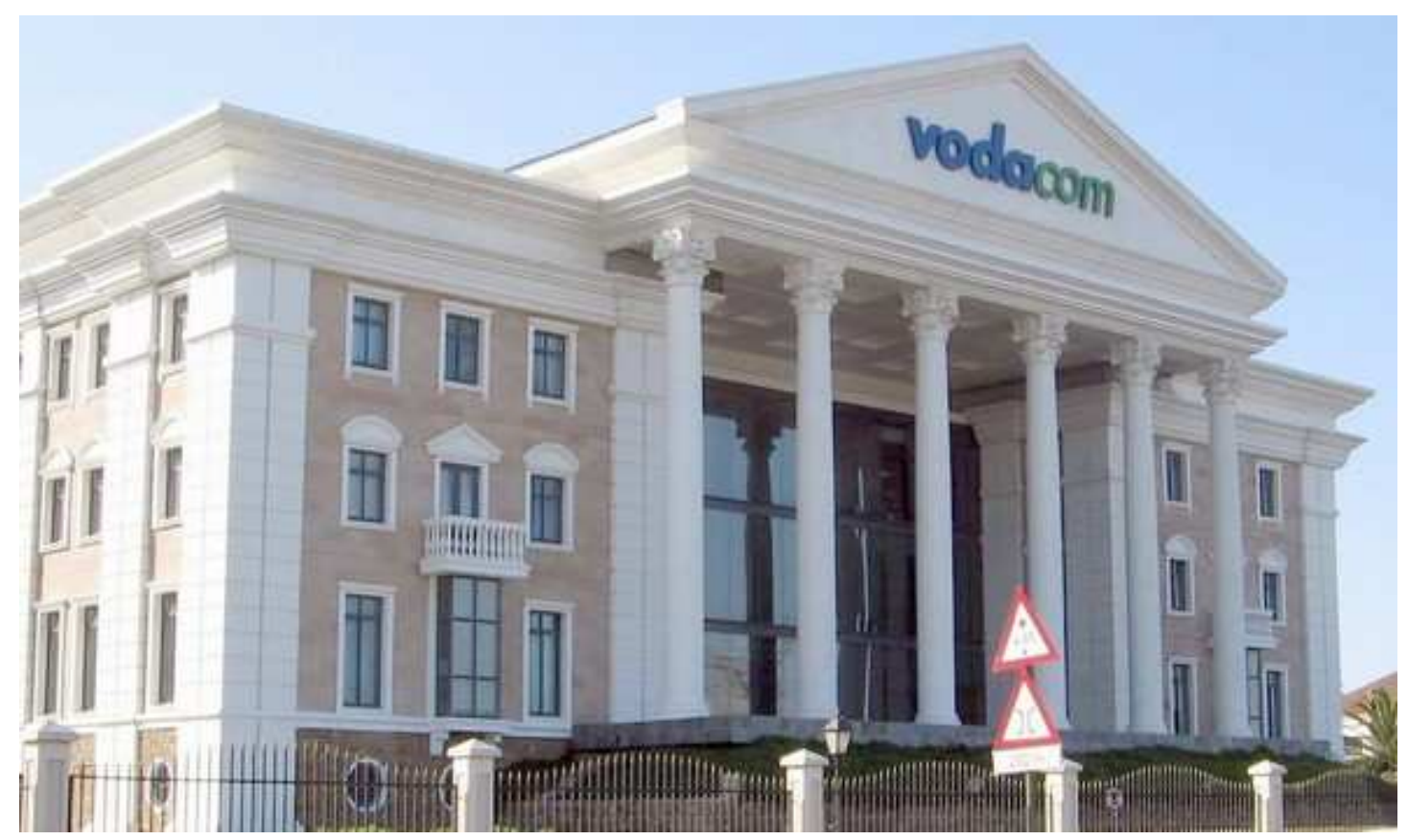

Fig. 11: Vodacom headquarters, Cape Town, c. 1990.

\section{BIBLIOGRAPHY}

Abdullah, A \& Pakenham, T C 1930. Dreamers of empire. London: George G. Harrap.

Baker, H 1934. Cecil Rhodes by his architect. London: OUP.

Blagg, T 1983. Architecture. In Henig, M (ed.) A handbook of Roman art, 26-65. Ithaca: Cornel University Press.

Davidson, A 1984. Trans. by C English 2003. Cecil Rhodes and his time. Pretoria: Protea Book House.

De Bosdari, C 1964. Cape Dutch houses and farms: their architecture and history, together with a note on the role of Cecil John Rhodes in their preservation. Cape Town: Balkema.

Edwards, C 2008. Possessing Rome: the politics of ruins in Roma Capitale. In Hardwick, L \& Stray, C (eds.) A companion to Classical receptions, 345-359. Malden, M A \& Oxford: Blackwell.

36 My thanks to Dr Phiroze Vasunia of the University of Reading for originally suggesting the topic and for an invitation to join his panel on Classical architecture entitled "An imperial vision" at the British Classical Association Conference, Liverpool, April 2008. The two anonymous referees for Akroterion are also thanked for their positive feedback and very useful suggestions. 
Evans, R 2007. Perspectives on post-colonialism in South Africa: the Voortrekker Monument's Classical heritage. In Hardwick, L \& Gillespie, C. Classics in post-colonial worlds, 141-165. Oxford: Oxford University Press.

Fensham, C 1986. Ou Hoofgebou, 'n eeu oud. Stellenbosch University, occasional publication.

Flint, J 1974. Cecil Rhodes. Boston: Little, Brown \& Company.

Greig, D E 1970. Herbert Baker in South Africa. Cape Town \& Johannesburg: Purnell.

Hardwick, L \& Gillespie, C 2007. Classics in post-colonial worlds. Oxford: Oxford University Press.

Hardwick, L \& Stray, C (eds.) 2008. A companion to Classical receptions. Malden, MA \& Oxford: Blackwell.

Henig, M (ed.) 1983. A handbook of Roman art. Ithaca: Cornel University Press.

Hofmeyr, S M 1993. Carl Otto Hager van Stellenbosch. Stellenbosch: Stellenbosch Museum.

"Imperialist" (= James Rutherford Maguire?) 1897. Cecil Rhodes: biography and appreciation, with personal reminiscences by Dr Jameson. London \& New York: Macmillan.

Johnson, B A 1987. Domestic architecture of the Cape, 1872-1912: Herbert Baker, his associates and his contemporaries. University of South Africa, D.Litt. \& Phil. Diss. (microfiche).

Marlowe, J 1972. Cecil Rhodes: The anatomy of empire. London: Paul Elek.

Maylam, P 2005. The cult of Rhodes: remembering an imperialist in Africa. Cape Town: David Philip.

Merrington, P 2001. A staggered orientalism: the Cape to Cairo imaginary. Poetics Today 22.2: 323-64.

Mertens, A $1971^{2}$. Stellenbosch. Cape Town: Tafelberg.

Metcalf, T R 1989. An imperial vision: Indian architecture and Britain's Raj. London: Faber and Faber.

Metcalf, T R 1980. Architecture and Empire. History Today 30 (12): 7-12.

Millin, S G 1937. Rhodes. London: Chatto \& Windus.

Radford, D J C 1992. Sir Herbert Baker. The architects of Parktown Series. Johannesburg: Parktown \& Westcliff Heritage Trust.

Roberts. B 1969. Cecil Rhodes and the princess. London: Hamish Hamilton.

Stead, W T 1902. The last will and testament of Cecil John Rhodes with elucidatory notes, to which are added some chapters describing the political and religious ideas of the testator. London: Review of Reviews Office.

Vermeulen, I 1999. Man en monument: die lewe en werk van Gerard Moerdijk. Pretoria: Van Schaik.

Williams, B 1921, $1938^{2}$. Cecil Rhodes. London: Constable.

\section{ILLUSTRATIONS}

Unless otherwise specified, all illustrations are photographs taken by the author. 